Jurnal IImiah AL-Jauhari (JIAJ)

Volume 4 No 1, (Juni 2019): 239-260

p-ISSN: $2541-3430$

e-ISSN: $2541-3449$

Website: http://journal.iaingorontalo.ac.id/index.php/aj

\title{
Alternatif Kajian Hadis sebagai Penafsir Alquran secara Tekstual
}

\author{
Abdullah Karim \\ Fakultas Ushuluddin dan Humaniora UIN Antasari Banjarmasin \\ karimabdullah215@gmail.com
}

\begin{abstract}
Textual interpretation of the Qur'an is the best interpretation, as long as the histories used as interpreters can be justified. The validity of the hadith which is used as the interpreter of the Qur'an must meet the following criteria: a. The interpretation of the Koran with the Koran must come from the Messenger of Allah. own. $b$. The interpretation of the Qur'an with the hadith must be based on the shahīh narration. c. Regarding the history of asbāb an-nuzūl, you must use a history whose expressions expressly indicate the cause of descending verses. $d$. The validity of the history used as the interpreter of the Qur'an will be more accurate if you consider the proportionality, professionalism and contextuality of the said traditions.
\end{abstract}

\begin{abstract}
Abstrak
Penafsiran Alquran secara tekstual merupakan penafsiran terbaik, selama riwayat-riwayat yang digunakan sebagai penafsir itu dapat dipertanggungjawabkan keabsahannya. Keabsahan hadis yang dijadikan penafsir Alquran dimaksud harus memenuhi kriteria berikut: a. Penafsiran Alquran dengan Alquran harus bersumber dari Rasul saw. sendiri. b. Penafsiran Alquran dengan hadis harus berdasarkan periwayatan yang shahī $\underline{h}$. c. Berkaitan dengan riwayat asbāb an-nuzūl harus menggunakan riwayat yang ungkapannya secara tegas menunjukkan sebab turun ayat. d. Keabsahan riwayat yang dijadikan penafsir Alquran tersebut akan lebih akurat jika mempertimbangkan proporsionalitas, profesionalitas dan kontekstualitas hadis-hadis dimaksud
\end{abstract}

Kata Kunci: Hadis: Tafsir; Alquran; Tekstual 


\section{Pendahuluan}

Penafsiran Alquran secara tekstual (at-Tafsīr al-Ma'tsūr), oleh para pakar 'ulūm al-Qur'ān / tafsir dianggap pendekatan tafsir yang terbaik, ${ }^{1}$ karena Alquran ditafsirkan oleh Alquran sendiri, atau Alquran ditafsirkan oleh hadis Rasul saw., atau Alquran ditafsirkan oleh $\bar{a} t s \bar{a} r$ para sahabat ra. Anggapan ini tentunya dapat diterima, ketika riwayat-riwayat yang dijadikan penafsiran Alquran tersebut dapat dipertanggungjawabkan keabsahannya, dengan ketentuan: pertama, para periwayatnya adalah orang-orang yang kapasitas intelektualnya mumpuni (dhābith) dan integritas keagamaannya baik ('ādil). ${ }^{2}$ Kedua, ada hubungan guru dan murid di antara para periwayat yang berdekatan (muttashil). ${ }^{3}$ Di samping itu, materi yang diriwayatkan (matn al-hadìts) atau ātsār tersebut tidak mengandung kejanggalan dan tidak cacat (baik karena bertentangan dengan kandungan Alquran secara umum, bertentangan dengan hadis yang kualitasnya lebih tinggi, bertentangan dengan fakta sejarah atau bertentangan dengan pemikiran akal sehat).

Sepanjang sejarah perkembangan tafsir Alquran, pendekatan tafsir tidak keluar dari penafsiran dengan riwayat (al-Ma'tsūr/almanqūl/bi ar-riwāyah/al-atsariy/ar-rawā'iy) dan non-riwayat (addirāyah/al-ma'qūl/bi ar-ra'yi/an-nazhariy/al-'aqliy), atau

\footnotetext{
*Guru Besar Tafsir/Ulūm al-Qur'ān pada Fakultas Ushuluddin dan Humaniora Universitas Islam Negeri Antasari Banjarmasin

${ }^{1}$ Lihat antara lain uraian yang dikemukakan oleh Ibnu Taymiyah, Muqaddimah fì Ushūl at-Tafsìr, (Bayrūt, Lubnān: Dār Ibni Hazm, 1418 H./1997 M.), Cet. ke-2, h. 84-93. Pendapat ini dikutip oleh Ibnu Katsīr dalam Muqaddimah tafsirnya dan as-Suyūthiy dalam al-Itqān fì 'Ulüm al-Qur'ān. Juga Fahd 'Abd arRahmān bin Sulaymān ar-Rūmiy, Ushūl at-Tafsīr wa Manāhijuh, (Riyādh: Maktabah at-Tawbah, 1413), Cet. ke-1, h. 71. Juga Badr ad-Dīn Muhammad bin 'Abdullāh az-Zarkasyiy, Al-Burhān fì 'Ulūm al-Qur'ān, Juz 2, (Bayrūt, Lubnān: Dār al-Fikr, 1408 H./1988 M.), h. 192. Juga asy-Syaykh Khālid 'Abd ar-Rahmān al'Akk, Ushūl at-Tafsìr wa Qawā'iduh, (Bayrūt: Dār an-Nafă'is, 1406 H./1986 M.), Cet. ke-2, h. 79-80.

${ }^{2}$ Orang yang memenuhi kedua kriteria ini oleh ulama 'Ulūm al- $\underline{\text { Hadìts }}$ diistilahkan dengan tsiqah. Lihat antara lain Jalāl ad-Dīn Abū al-Fadhl 'A $\bar{b}$ d arRaḥmān as-Suyūthiy, Tadrīb ar-Rāwiy Syarh Taqrīb an-Nawawiy, tah̄īiq 'Irfān al'Asyā Hasūnah, (Bayrūt, Lubnān: Dār al-Fikr,1420 H./2000 M.), h. 31.

${ }^{3}$ Dimaksudkan dengan istilah muttashil adalah bahwa semua periwayat yang berdekatan dalam sebuah sanad (mata rantai periwayat hadis), bersambung, seperti periwayat pertama adalah guru dari periwayat kedua, periwayat kedua adalah guru dari periwayat ketiga dan seterusnya.
} 
menggabungkan keduanya secara signifikan (an-naqdiy). ${ }^{4}$ Dalam tulisan ini, penulis menggunakan istilah pendekatan untuk al-Ma'tsūr, al-ma'qūl dan yang menggabungkan keduanya secara signifikan (annaqdiy), karena secara metodologis, ketiganya dapat memayungi metode-metode tafsir. Dalam arti, bahwa seorang mufasir dapat melakukan pendekatan-pendekatan ini dalam karya tafsirnya dengan menggunakan metode tafsir apa pun, baik analitis (tahlililiy), global

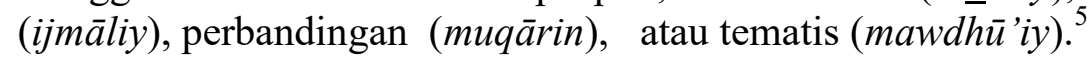

Dalam hal ini, penafsiran dengan isyarat (at-Tafsīr al-isyāriy) dimasukkan dalam kategori non-riwayat, karena memang tidak menggunakan riwayat. Oleh karena itu, penafsiran ini dapat dikategorikan tafsir yang terpuji ( $m a \underline{h} m \bar{u} d)$ atau dapat pula menjadi tafsir yang tercela (madzmūm).

Para ulama 'ulüm al-Qur'ān / tafsir sepakat bahwa at-tafsìr bi ar-ra'yi al-mahmūd adalah penafsiran Alquran berdasar penalaran yang berjalan sesuai dengan pembicaraan orang Arab, kebiasaan mereka dalam membicarakan sesuatu, sesuai pula dengan Alquran dan as-Sunnah serta memenuhi semua persyaratan penafsiran, ${ }^{6}$ sedangkan at-tafsīr bi ar-ra'yi al-madzmūm, adalah penafsiran Alquran yang mufasirnya tidak memenuhi persyaratan yang telah ditentukan dan

${ }^{4}$ Muhammad az-Zafzāf, At-Ta'rīf bi al-Qur'ān wa al-Hiadīts, (t.d.), Cet. ke1, h. 164; Shalāh 'Abd al-Fattāh al-Khālidiy, Ta'rīf ad-Dārisīn bi Manāhij alMufassirīn, (Damsyiq: Dār al-Qalam/Bayrūt: ad-Dār asy-Syāmiyah, 1423 H./2002 M.), Cet. ke-1, h. 200; Juga Muhammad 'Alī ash-Shābūniy, At-Tibyān fì 'Ulūm alQur'ān, (Jakarta: Dār al-Kutub al-Islāmiyyah, 1424 H./2003 M.), Cet. ke-1, h. 67 dan 155. Ibnu 'Āsyūr menggunkan istilah al-Atsariy, an-Nazhariy, dan al-Atsariy an-Nazhariy (an-Naqdiy). Lihat Muhammad al-Fādhil bin 'Āsyūr, At-Tafsīru wa Rijāluh, (al-Qāhirah: Majma’ al-Buhūūts al-Islāmiyyah, 1390 H./1970 M.), 14 dan seterusnya.

${ }^{5}$ Pembahasan mengenai metodologi tafsir ini dapat dilihat antara lain 'Abd al-Hayy al-Farmāwiy, Al-Bidāyah fì at-Tafsìr al-Mawdhū'iy, (Al-Qāhirah: Fakultas Ushuluddin Universitas al-Azhar, 1425 H./2005 M.), Cet. ke-7, h. 19.

${ }^{6}$ Muhammad Husayn adz-Dzahabiy, At-Tafsīr wa al-Mufassirūn Juz 1, (alQāhirah: Maktabah Wahbah, 1424 H./2003 M.), Cet. ke-8, h. 189; az-Zarkasyiy, alBurhān..., Juz 2, h. 179; Muhammad 'Abd al-'Azhīm az-Zarqāniy, Manāhil al'Irfān fì 'Ulūm al-Qur'ān, Jilid 2, (Bayrūt: Dār al-Fikr, t. th.), h. 49; Al-'Akk, Ushūl at-Tafsīr..., h. 171; Mushthafā Ibrāhīm al-Masyīniy, Madrasah al-Tafsīr fì alAndalus, (Bayrūt: Mu'assasah ar-Risālah, 1406 H./1986 M.), Cet. ke-1, h. 144; AlKhālidiy, Ta'rīf ad-Dārisīn..., h. 417; Ash-Shābūniy, at-Tibyān..., h. 157; Bakriy Syaykh Amīn, at-Ta'bìr al-Fanniy fì al-Qur'ān al-Karīm, (Bayrūt, Lubnān: Dār al'Ilmi li al-Malāyīn, 1994), Cet. ke-1, h. 108. Juga Muhammad Hamd Zaglūl, AtTafsìr bi ar-Ra'yi: Qawā'iduhū wa Dhawābithuhū wa A'lāmuh, (Damsyiq: Maktabah al-Fārābiy, 1420 H./1999 M.), Cet. ke-1, h. 108. 
semata-mata mengandalkan penalaran, tanpa ada dasar yang dapat dijadikan pegangan. ${ }^{7}$

Tulisan ini akan difokuskan pada pembahasan tentang pendekatan at-Tafsìr al-Ma'tsūr dan lebih khusus lagi akan menyoroti pertanggungjawaban akurasi riwayat. Hal utama yang akan disoroti berkaitan dengan periwayatan dimaksud, diarahkan pada: Bagaimana proporsionalitas Rasul sebagai penafsir Alquran? Bagaimana para ahli hadis mendudukkan hadis-hadis tafsir mereka secara profesional dalam karya-karya mereka?; serta dalam konteks apa saja hadis-hadis itu disampaikan?

Spesifikasi karya ini adalah bahwa hadis dianalisis dalam fungsinya sebagai penafsir Alquran sesuai dengan tugas Rasul sebagai mubayyin al-Qur'ān, penempatan hadis secara professional oleh para mukharrij (penghimpun hadis yang mempublikasikan karyanya) dalam kitāb at-Tafsìr dan mencermati konteks yang melingkungi munculnya hadis atau lebih jauh memahami substansi hadis itu berbicara dalam konteks apa saja. Sementara kajian kritik hadis pada umumnya adalah dalam rangka mencari keabsahan hadis, apakah betul berasal dari Rasul saw. atau tidak, sehingga menghasilkan penetapan

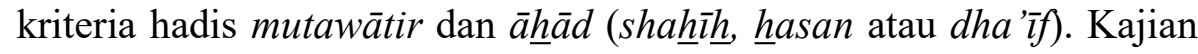
terakhir ini juga tetap diperhatikan, karena hadis $d$ ha'if termasuk hadis yang tidak dapat dipertanggungjawabkan kebenarannya, tanpa didukung oleh hadis lainnya yang berkualitas shahīh $\underline{\text {, atau }} \underline{\operatorname{hasan}}$.

\section{Pembahasan}

Ketika penulis melakukan penelitian berjudul: Reinterpretasi Ayat-Ayat Bias Gender (Interpretasi Analitis Sūrah An-Nisā Ayat Satu dan 34), yang mendapatkan Dana DIKS IAIN Antasari Banjarmasin tahun 2003, penulis menemukan bahwa semua mufasir yang menggunakan riwayat sebagai pendekatan tafsirnya menyimpulkan bahwa $\underline{H} a w w \bar{a}$ diciptakan oleh Allah dari tulang rusuk Ādam. Bertolak dari temuan tersebut, penulis berusaha melacak hadis-hadis terkait untuk memastikan apakah hadis-hadis itu dapat diposisikan sebagai penafsir ayat satu Sūrah an-Nisā. Hasil penelitian menunjukkan bahwa Rasul dengan hadis-hadis tersebut tidak bermaksud menafsirkan Sürah an-Nisā ayat satu tersebut, begitu pula dengan para ahli hadis yang memuat hadis-hadis dimaksud tidak menempatkannya dalam kitāb at-Tafsìr (dalam arti bagian atau bab

${ }^{7}$ Az-Zarkasyiy, al-Burhān ..., Juz 2, h. 187; az-Zarqāniy, Manāhil al'Irfān..., Jilid 2, h. 49; adz-Dzahabiy, at-Tafsīr..., Jilid 1, h. 189; al-'Akk, Ushūl atTafsīr..., h. 171; al-Masyīniy, Madrasah at-Tafsīr..., h. 145; al-Khālidiy, Ta'rīf adDārisīn..., h. 417; Ash-Shābūniy, at-Tibyān..., h. 157; Bakrī Syaykh Amīn, atTa'bìr al-Fanniy..., h. 107; Juga Juga Zaglūl, at-Tafsìr bi ar-Ra 'yi..., h. 108. 
yang berkaitan dengan penafsiran ayat-ayat Alquran) mereka. Lebih jauh lagi, dengan memperhatikan hadis-hadis terkait, dapat dipahami bahwa hadis-hadis dimaksud tidak berbicara tentang asal-usul kejadian $\underline{H} a w w \bar{a}$, tetapi berbicara dalam hal pembinaan rumah tangga, yang mana seorang suami dalam rumah tangga, jika berkeinginan meluruskan sikap, tindakan, atau pekerjaan isterinya, hendaknya memberinya nasehat dengan cara yang arif dan bijaksana, karena wanita itu bagaikan tulang rusuk yang bengkok, sulit (baca mustahil) untuk meluruskannya. Walaupun berhasil meluruskannya, maka tulang rusuk itu berarti pecah dan pecahnya tulang rusuk itu adalah kiasan (metafora) dari terjadinya perceraian. ${ }^{8}$

\section{Kajian Hadis Proporsional}

At-Tafsìr bi al-Ma'tsūr, yang juga disebut al-tafsīr bi almanqūl atau al-tafsīr bi al-riwāyah atau at-Tafsìr ar-rawā'iy (interpretasi tekstual) adalah "penjelasan atau perincian yang datang dari Alquran, riwayat yang dinukil dari Rasul saw., para sahabat dan para tabiin, yang menjelaskan apa yang Allah kehendaki dari nashnash yang terdapat dalam Alquran". ${ }^{9}$ Dari definisi ini dapat diketahui bahwa dalam pendekatan ini, tidak termasuk penafsiran dengan ijtihād atau penyimpulan. ${ }^{10}$ Dalam hal ini, seorang mufasir dianggap mengikuti pendekatan penafsiran bi al-ma'tsūr, jika penafsirannya didominasi oleh penggunaan riwayat, walaupun untuk hal-hal tertentu dia menggunakan penalaran.

Menindaklanjuti rekomendasi yang penulis sampaikan dalam penelitian yang diselesaikan pada tahun 2003 yang lalu, penulis bermaksud mencermati hadis-hadis yang digunakan sebagai penafsir Alquran, dilihat dari tugas Rasul saw. sebagai pemberi penjelasan Alquran (mubayyin al-Qur'ān).

Menurut adz-Dzahabiy, penjelasan Rasul saw. terhadap Alquran itu mencakup:

a. Menjelaskan yang global dalam Alquran,

b. Menjelaskan yang sulit (musykil),

c. Mengkhususkan yang umum, dan

d. Mengaitkan yang mutlak. ${ }^{11}$

\footnotetext{
${ }^{8}$ Abdullah Karim, Reinterpretasi Ayat-AyatBias Gender (Interpretasi Analitis Sūrah an-Nisā Ayat Satu dan 34), (Banjarmasin: Puslit IAIN Antasari, 2003), h. 32-52.

${ }^{9}$ Adz-Dzahabiy, al-Tafsīr..., Jilid 1, h. 112; Juga Zaglūl, al-Tafsīr bi arRa'yi..., h. 103.

${ }^{10}$ Zaglūl, al-Tafsīr bi ar-Ra'yi..., h. 103.

${ }^{11}$ Adz-Dzahabiy, At-Tafsīr..., Juz 1, h. 43. Juga Fahd ar-Rūmiy, Ushūl atTafsīr..., h. 19. Untuk hadis "Dan salatlah kalian sebagaimana kalian melihatku
} 
Lebih lanjut, ar-Rūmiy menambahkan bahwa Nabi saw. juga menjelaskan makna lafal atau memberikan komentar terhadap lafal tertentu. ${ }^{12}$

Berikut akan dikemukakan beberapa contoh penafsiran Rasul:

Pertama, penjelasan Rasul terhadap sesuatu yang masih global dalam Alquran. Rasulullah saw. menjelaskan waktu salat yang lima, jumlah rakaatnya dan cara melakukannya. Untuk itu Rasul saw. bersabda: "Dan salatlah kalian sebagaimana kalian melihat aku salat". ${ }^{13}$ Atau ketentuan-ketentuan wajib zakat, waktu-waktunya dan macam-macamnya. Begitu pula dengan manāsik haji. Untuk itu beliau bersabda: "Ambillah dariku manasik haji kalian". ${ }^{14}$

Dari contoh pertama ini dapat diketahui bahwa Rasul saw. menjelaskan secara rinci apa yang dalam Alquran masih bersifat global. Dalam hal ini, sekalipun makna lafal ayat-ayat dimaksud dapat diketahui, seperti; salat, zakat dan haji, namun belum dapat dilaksanakan tanpa perincian yang diberikan oleh Rasul saw.

Kedua, penjelasan Rasul terhadap sesuatu yang sulit dipahami, karena makna yang diinginkan bukanlah makna lafal menurut pengertian leksikal (makna kata dalam kamus bahasa). Ketika Sürah al-Baqarah ayat 187 yang berarti: ...makan dan minumlah kalian, sampai terang benang putih dari benang hitam, yaitu fajar.

Imam al-Bukhāriy mengemukakan tiga buah hadis berkaitan dengan ayat ini:

Pertama, Mūsā bin Ismā'îl menyampaikan hadis ini kepada kami, katanya Abū 'Uwānah menyampaikan hadis ini kepada kami, katanya dari Hushayn, dari asy-Sya'biy, dari 'Adiy yang berkata: Saya mengambil seutas benang putih dan seutas benang hitam. Ketika tinggal sebagian malam, saya melihat kedua benang tersebut, tetapi tidak tampak kelihatan. Ketika pagi hari, saya bertanya kepada Rasul:

salat', lihat Abū 'Abdillāh Muhammad bin Ismā’̄il bin Ibrāhīm bin al-Mugīrah bin

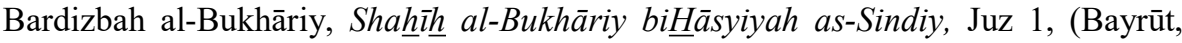
Lubnān: Dār al-Fikr, 1414 H./1994 M.), h. 145.

${ }^{12}$ Fahd ar-Rūmiy, Ushül at-Tafsīr..., h. 19.

${ }^{13}$ Adz-Dzahabiy, At-Tafsīr..., Juz 1, h. 43. Juga Ibrāhīm bin Muhammad

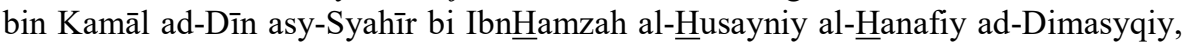
Al-Bayān wa at-Ta'rīf fì Asbāb Wurūd al-Hadīts asy-Syarīf, Juz 1, (Bayrūt, Lubnān: Al-Maktabah al-'Ilmiyyah, 1402 H./1982 M.), h. 22.

${ }^{14}$ Redaksi hadis ini berasal dari Ahmad bin Hanbal. Muslim mengemukakan redaksi yang sedikit berbeda, yaitu: Hendaknya kalian mengambil manasik kalian, karena aku tidak mengetahui, barangkali aku tidak mengerjakan haji

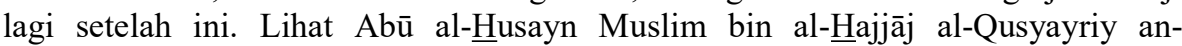
Naysābūriy, Shạ̄hㅡ Muslim bi Syarh an-Nawawiy, Juz 2, (Indonesia: Maktabah Dahlān, t. th.), h. 943. Juga Ibrāhīm bin Muhammad bin Kamāl ad-Dīn, Al-Bayān wa at-Ta'rīf..., Juz 1, h. 22. 
Hai Rasul Allah, saya menaruh benang di bawah bantalku. Rasulullah saw. bersabda: Kalau begitu, bantal Anda sangat lebar, jika benang putih dan benang hitam itu di bawah bantal Anda (Hadis nomor 4509). ${ }^{15}$ Ungkapan "Kalau begitu bantal anda sangat lebar", karena yang dimaksudkan dengan benang putih dan benang hitam itu adalah rentang waktu antara gelapnya malam dan terangnya siang (fajar shādiq).

Kedua, Qutaybah bin Sa'̄id menyampaikan hadis ini kepada kami, katanya Jarīr bin Mutharrif menyampaikan hadis ini kepada kami, katanya dari asy-Sya'biy, dari 'Adiy bin Abī Hātim ra. Dia berkata: Hai Rasul Allah, apa yang dimaksud dengan benang putih dan benang hitam itu, apakah benang sungguhan? Rasul bersabda: Anda adalah orang yang paling patuh, jika Anda melihat kedua benang tersebut. Kemudian Rasul bersabda pula: Bukan itu yang dimaksudkan, tetapi gelapnya malam dan terangnya siang (Hadis nomor 4510). ${ }^{16}$

Ketiga, Ibnu Maryam menyampaikan hadis ini kepada kami, katanya Abū Gassān Muhammad bin Mutharrif menyampaikan hadis ini kepada kami, katanya Abū Hāzim menyampaikan hadis ini kepada saya, dari Sahl bin Sa'd, dia berkata: Ketika diturunkan ayat yang berarti "..makan dan minumlah kalian, sampai terang benang putih dari benang hitam" dan belum diturunkan ayat yang berarti "yaitu fajar". Karena itu, ada beberapa orang, yang jika ingin berpuasa, mereka mengikatkan benang putih dan hitam di kaki mereka, mereka makan-makan sampai jelas kelihatan benang putih dari benang hitam. Setelah itu, Allah menurunkan ayat yang berarti "yaitu fajar". Kemudian mereka mengetahui bahwa yang dimaksudkan adalah gelapnya malam dan terangnya siang. Itulah waktu fajar, yaitu fajar shādiq. ${ }^{17}$

Dari contoh kedua ini, semakin jelas bahwa ungkapan benang hitam dan benang putih, yang dimaksudkan bukanlah makna hakiki (denotasi), tetapi makna majazi (konotasi) yaitu gelapnya malam dan terangnya siang. Contoh ini, di samping menjelaskan makna terhadap kata yang sulit dipahami, juga termasuk kategori menafsirkan Alquran dengan Alquran. Dalam hal ini, jika hal itu dilakukan oleh Rasul saw. sendiri, maka termasuk at-Tafsīr bi al-Ma'tsūr ${ }^{18}$ begitu pula àtsār

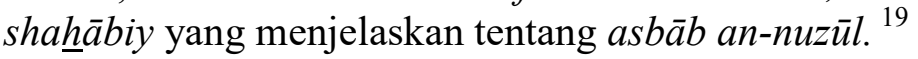

\footnotetext{
${ }^{15}$ Al-Bukhāriy, Shah̄īh al-Bukhāriy..., Juz 3, h. 104.

${ }^{16}$ Al-Bukhāriy, Sha $\underline{h} \overline{\underline{h}}$ al-Bukhāriy.... Juz 3, h. 104.

${ }^{17}$ Al-Bukhāriy, Shạ̄̄ㅡ al-Bukhāriy..., Juz 3, h. 104.

${ }^{18}$ Al-Khālidiy keberatan penafsiran Alquran dengan Alquran ini dimasukkan kategori at-tafsīr bi al-ma'tsūr, karena menurutnya kalam Allah itu tidak melalui periwayatan sebagaimana hadis Rasul. Lihat al- Khālidiy, Ta'rīf ad-
} 
Ketiga, penjelasan Rasul yang mengkhususkan sesuatu yang bersifat umum. Al-Bukhāriy mengemukakan hadis berikut: 'Umar bin Hafsh bin Giyāts menyampaikan hadis ini kepada kami, katanya: alA'masy menyampaikan hadis ini kepada kami, dia berkata: Ibrāhīm menyampaikan hadis ini kepadaku, dari 'Alqamah, dari 'Abdullāh ra. Dia berkata: Ketika diturunkan Sürah al-An'ām ayat 82 yang terjemahnya: "Orang-orang yang beriman dan mereka tidak mencampuradukkan keimanan mereka itu dengan kezaliman..." kami bertanya: Siapa di antara kami yang tidak pernah menzalimi dirinya? Rasul bersabda: (Pengertiannya) tidak seperti apa yang kalian pahami dan kalian katakan. Yang dimaksudkan dengan tidak mencampuradukkan keimanan mereka itu dengan kezaliman, adalah syirik. Tidakkah kalian mendengar perkataan Luqmān terhadap anaknya: "Hai anakku, janganlah kamu mensyarikatkan Allah, sesungguhnya syirik itu adalah kezaliman yang besar". ${ }^{20}$ (Surah Luqmān ayat 13)

Dari contoh ketiga ini, ketegasan makna yang diinginkan tampak lebih jelas lagi. Rasul menyatakan bahwa makna kezaliman pada Sürah al-An'ām ayat 82 adalah syirik yang terdapat pada Sürah Luqmān ayat 13, bukan makna leksikal (yang ada dalam kamus bahasa) seperti yang dipahami oleh para sahabat. Contoh ini, di samping mengkhususkan makna yang umum, yaitu kezaliman diberi makna syirik, juga termasuk kategori menafsirkan Alquran dengan Alquran.

Keempat, penjelasan Rasul yang mengaitkan sesuatu yang bersifat mutlak. Berkaitan dengan Sürah al-Mā'idah ayat 38 yang artinya: "Laki-laki dan perempuan yang mencuri potonglah tangan keduanya (sebagai) pembalasan bagi apa yang telah mereka kerjakan dan sebagai siksaan dari Allah. Dan Allah Maha Perkasa lagi Maha Bijaksana".

Dārisin..., h. 148. Akan tetapi, sebagaimana contoh yang dikemukakan ini, penafsiran tersebut dilakukan oleh Rasul. Periwayatan bahwa Rasul menafsirkan Alquran dengan Alquran inilah yang mengharuskannya termasuk kategori at-tafsir bi al-ma'tsūr.

${ }^{19}$ Ini berdasarkan pendapat Ibn ash-Shalāh dan an-Nawawī, Di sini mereka menganggap pernyataan sahabat berkaitan dengan sebab turun ayat itu, sebagai riwayat yang $m a r f \bar{u}$, sementara al-Hāāim lebih longgar, dia beranggapan bahwa semua yang datang dari sahabat dianggap marf $\bar{u}$ ', tidak terbatas pada sabab al-nuzūl saja. Lihat adz-Dzahabiy, at-Tafsìr ..., Jilid 1, h. 96

${ }^{20}$ Al-Bukhāriy, Sha hīh al-Bukhāriy, Juz 2, h. 269. Hadis nomor 3360. Hadis ini dikemukakan pula oleh al-Bukhāriy ketika menjelaskan makna kezaliman dalam arti yang lain. Lihat Juz 1, h. 16. Di situ dia menjelaskan sejumlah hadis yang sama, yaitu hadis-hadis dengan nomor: 3360, 3428, 3429, 3629, 4629, 4776, 6918, dan 6937. 
Imām an-Nasā'iy mengemukakan tujuh riwayat yang menjelaskan nilai curian yang dapat dikenakan potong tangan. Tiga riwayat menjelaskan batasnya Lima Dirham dan empat riwayat lainya menjelaskan batasnya hanya Tiga Dirham. ${ }^{21}$ Salah satu riwayat yang dikemukakan oleh an-Nasā'iy tersebut adalah: Qutaybah menginformasikan hadis ini kepada kami, katanya dari Mālik, dari Nāfi', dari Ibnu 'Umar, bahwa Rasul saw. memotong tangan (pencuri) perisai yang harganya Tiga Dirham. ${ }^{22}$

Dari contoh keempat ini dapat diketahui bahwa pencuri yang di dalam Alquran diungkapkan secara mutlak, oleh Rasul dikaitkan bahwa pencuri yang dapat dipotong tangannya itu adalah jika nilai curiannya mencapai batas minimal Tiga Dirham.

Kelima, penjelasan Rasul terhadap makna lafal atau komentar beliau terhadap lafal tertentu.

Berkaitan dengan penafsiran Sürah al-Baqarah ayat 22 yang berarti: "Maka janganlah kalian jadikan sekutu-sekutu bagi Allah...". Al-Bukhāriy meriwayatkan: 'Utsmān bin Ab̄̄ Syaybah menyampaikan hadis ini kepadaku, katanya: Jarīr menyampaikan hadis ini kepada kami, katanya: dari Manshūr, dari Ab̄̄ Wā'il, dari 'Umar bin Syurahbīl, dari 'Abdullah, dia berkata: Saya bertanya kepada Nabi saw.: Dosa apa yang paling besar terhadap Allah? Rasul menjawab: Anda jadikan sekutu bagi-Nya, padahal Dia telah menciptakan Anda? Saya katakan: Itu dosa yang sangat besar. Setelah itu apa lagi? Dia menjawab: Anda membunuh anak Anda karena Anda takut anak itu makan bersama Anda. Saya bertanya pula: Setelah itu apa lagi? Dia menjawab: Anda berzina dengan isteri tetangga Anda. ${ }^{23}$

Al-Bukhāriy meriwayatkan pula: 'Abdullāh bin Yūsuf menyampaikan hadis ini kepada kami, katanya Mālik menginformasikan hadis ini kepada kami, katanya dari Sumayy bin Abī Shālih̆, dari Abū Hurayrah ra. bahwa Rasul saw. bersabda: Apabila Imam membaca: gayri al-magdhūbi 'alayhim wa là adhdhällìn, maka hendaklah kalian membaca āminn. Karena, siapa saja yang membacanya berbarengan dengan para malaikat, maka orang itu diampuni dosa-dosanya yang lalu. (Hadis nomor 4475). ${ }^{24}$ Contoh kelima ini mendeskripsikan komentar Rasul terhadap ayat Alquran, sekaligus berisi bimbingan dalam rangka ibadah salat berjamaah.

\footnotetext{
${ }^{21}$ Lihat Abū 'Abd ar-Rahmmān Aḥmad bin Syu'ayb an-Nasā'iy, Sunan anNasā'iy bi Syarh as-Suyūthiy wa $\underline{\text { H}} \bar{a}$ syiyah as-Sindiy, Juz 8, (Semarang: Toha Putra, t. th.), h. 76-77.

${ }^{22}$ An-Nasā'iy, Sunan an-Nasā'iy, Juz 8, h. 76.

${ }^{23}$ Al-Bukhāriy, Sha h̄i $\underline{h}$ al-Bukhāriy, Juz 3, h. 97.

${ }^{24}$ Al-Bukhāriy, Shahㅡㄲㅡ al-Bukhāriy, Juz 3, h. 96.
} 
Dari contoh-contoh yang telah dikemukakan terdahulu, dapat diketahui bahwa baik penafsiran Alquran dengan Alquran atau penafsiran Alquran dengan hadis, semuanya disandarkan kepada riwayat yang berasal dari Rasul sendiri. Artinya, dalam hal ini, jika penafsiran ayat Alquran dengan ayat Alquran, tetapi tidak disandarkan kepada riwayat yang berasal dari Rasul, maka tidak termasuk penafsiran tekstual (at-Tafsìr al-Ma'tsür). Contoh berikut ini akan memperjelas bahwa penafsiran Alquran dengan Alquran itu harus berdasarkan riwayat.

Ibnu Mardawayh mengeluarkan hadis dari Anas, yang mengatakan: Seorang laki-laki datang kepada Rasul saw. seraya bertanya: Hai Rasul Allah, Allah menyebutkan (dalam Alquran): Talak itu dua kali, (sedangkan dalam Islam ada tiga kali), maka mana talak yang ketiga? Rasul menjawab: Setelah (talak yang kedua) itu boleh rujuk lagi dengan cara yang ma'rūf atau menceraikannya dengan cara yang baik ${ }^{25}$ (Q. S. Al-Baqarah: ayat 229). Inilah talak yang ketiga itu, karena ayat ini merupakan lanjutan dari ayat yang menjelaskan talak itu dua kali. Hadis ini dikemukakan sebagai pelengkap penjelasan sebelumnya.

Contoh lainnya adalah penafsiran Alquran dengan hadis qudsiy, sebagaimana dikemukakan oleh al-Bukhāriy berkaitan dengan penafsiran Sūrah al-Baqarah ayat 116 yang terjemahnya: Dan mereka (orang-orang kafir) berkata: "Allah mempunyai anak". Maha Suci Allah...Al-Bukhāriy mengatakan: Abū al-Yamān menyampaikan hadis ini kepada kami, katanya: Syu'ayb menginformasikan hadis ini kepada kami, katanya: dari 'Abdullāh bin Abī Husayn, katanya: Nāfi' bin Jubayr menyampaikan hadis ini kepada kami, katanya: dari Ibnu 'Abbās ra. dari Nabi saw., beliau bersabda: Allah swt. berfirman: "Manusia mendustakan Aku, padahal itu tidak ada pada-Nya. Manusia juga mencaci Aku, padahal itu tidak ada pada-Nya. Adapun dia mendustakan Aku, karena dia menganggap aku tidak mampu mengembalikannya seperti semula (membangkitkannya pada hari kiamat setelah meninggal), sedangkan dia mencela Aku, karena dia mengatakan: bahwa Aku punya anak. Maha Suci Aku dari mempunyai isteri dan anak". ${ }^{26}$

Contoh lainnya, berkenaan dengan sebab turun ayat 14 Sürah al-Baqarah yang terjemahnya: Dan bila mereka berjumpa dengan orang-orang yang beriman, mereka mengatakan: "Kami telah

\footnotetext{
${ }^{25}$ Muhammad 'Abd ar-Rahīim Muhammad, At-Tafsīr an-Nabawiy: Khashā'ishuh wa Mashādiruh, (Al-Qāhirah: Maktabah az-Zahrā, 1413 H./1992 M.), Cet. ke-1, h. 63. Sebagaimana dikutip dari as-Suyūthiy, al-Itqān..., Juz 2, h. 246.

${ }^{26}$ Al-Bukhāriy, Shahīh al-Bukhāriy..., Juz 3, h. 98.
} 
beriman". Al-Kalbiy mengatakan: dari Abī Shāliḥ, dari Ibnu 'Abbās, yang mengatakan: ayat ini diturunkan berkaitan dengan 'Abdullah bin Ubayy dan teman-temannya. Hal itu terjadi pada suatu hari, ketika mereka keluar, mereka bertemu dengan sekelompok sahabat Rasul saw. Abdullah bin Ubayy berkata (kepada teman-temannya): "Lihatlah, bagaimana aku mengusir orang-orang bodoh itu dari kalian?" Dia pun pergi, memegang tangan Abū Bakr seraya berkata: Selamat datang as-Siddīq, pemimpin Ban̄̄ Qayyim dan tokoh Islam; orang kedua yang bersama Rasul saw. di dalam Gua Tsūr dan mengerahkan jiwa dan hartanya untuk Rasul Allah. Kemudian dia memegang tangan 'Umar seraya berkata: Selamat datang pemimpin Ban̄̄ 'Adiy bin Ka'b, al-Fārūq yang kuat dalam memegang agama Allah, serta yang mengerahkan jiwa dan hartanya untuk Rasul Allah. Setelah itu dia memegang tangan 'Aliy seraya berkata: Selamat datang saudara sepupu Rasul dan menantunya, pemimpin Ban̄̄ Hāsyim selain Rasūl. Setelah itu mereka berpisah. Abdullāh bin Ubayy berkata kepada teman-temannya. Bagaimana kalian melihat apa yang telah kukerjakan? Jika kalian melihat mereka, lakukanlah seperti apa yang kukerjakan tadi. Mereka memujinya dan menganggapnya baik. Orangorang Islam pun pulang kepada Rasul dan menginformasikan pengalaman mereka, lalu ayat ini diturunkan. ${ }^{27}$

Untuk mengenali asbāb an-nuz $\bar{u} l$ ini, harus bersandar kepada periwayatan yang shahih $\underline{h}$ dan dengan ungkapan yang tegas menyebutkan sebab turun ayat atau ungkapan yang mencakup pengertian tersebut. ${ }^{28}$ Berkaitan dengan riwayat as $\bar{a} \bar{b}$ an-nuz $\bar{u} l$ ini, ketegasan yang dimaksudkan adalah "sebab turun ayat ini begini", "terjadi peristiwa begini atau Rasul saw. ditanya orang tentang sesuatu begini" lalu ayat Alquran diturunkan. ${ }^{29}$ Jika dikonfirmasikan dengan riwayat di atas, secara jelas ditemukan ungkapan "lalu ayat ini diturunkan". Dengan demikian dapat dipahami bahwa riwayat ini memang menginformasikan sebab turunnya ayat tersebut. Dan sahabat Rasul yang meriwayatkannya adalah Abdullāh bin 'Abbās. Sedangkan ungkapan yang menunjukkan pengertian sebab turun ayat adalah apa yang dikemukakan oleh Ibnu 'Abbās pada awal riwayat tersebut, yaitu: "ayat ini diturunkan berkaitan dengan 'Abdullah bin Ubayy dan teman-temannya".

\footnotetext{
${ }^{27}$ Abū al-Hasan 'Aliy bin Ahmad al-Wāhidiy an-Naysābūriy, Asbāa anNuzūl, (Jakarta: Dinamika Berkah Utama, t.th.), h. 13.

${ }^{28}$ Mannā' Qaththān, Mabāhits fì 'Ulūm al-Qur'ān, (Riyādh: Mansyūrāt al'Ashr al-Hadìts, 1973), h. 85.

${ }^{29}$ Mannā' Qaththān, Mabāhits..., h. 85 .
} 


\section{Kajian Hadis Profesional}

Kajian hadis profesional ini dimaksudkan untuk mengenali bagaimana para ahli (mukharrij) hadis menyusun hadis-hadis tafsir dalam kitab hadis mereka. Dalam hal ini dapat diinformasikan sebagai berikut:

1. Al-Bukhāriy menyusun hadis-hadis yang menafsirkan ayat-ayat Alquran dalam satu kitāb dalam arti bab atau bagian ke-65. Bagian dimaksud dapat ditemukan pada juz 3 halaman 96 sampai dengan 235.

2. Muslim menyusun hadis-hadis yang menafsirkan ayat-ayat Alquran dalam satu kitāb dalam arti bab atau bagian ke-54. Bagian dimaksud dapat ditemukan pada juz 4, halaman 2312 sampai dengan halaman 2323.

3. At-Turmudziy menyusun hadis-hadis yang menafsirkan ayat-ayat Alquran dalam satu kitāb dalam arti bab atau bagian ke-44. Bagian dimaksud dapat ditemukan pada juz 4, halaman 268 sampai dengan halaman 380 dan juz 5, halaman 3 sampai dengan halaman 124.

Ketiga ulama hadis inilah yang menghimpun hadis-hadis tafsir secara khusus dalam satu bagian dari kitab hadis yang mereka keluarkan. Dengan demikian, jika berkeinginan mengkonfirmasikan hadis-hadis yang digunakan sebagai penafsir Alquran, kita dapat merujuk kepada ketiga kitab hadis ini. Kitab-kitab hadis lainnya tidak memuat secara khusus hadis-hadis tafsir dimaksud.

Sebagai contoh, akan dikemukakan hadis-hadis yang digunakan oleh para mufasir ${ }^{30}$ yang menggunakan hadis sebagai penafsir Sürah an-Nisā ayat satu, kemudian akan dikonfirmasikan kepada kitāb at-Tafsīr yang memuat hadis-hadis tafsir. Hadis-hadis dimaksud adalah sebagai berikut:

\footnotetext{
${ }^{30}$ Para mufasir dimaksud antara lain adalah: 1. Ath-thūsiy $(385-460 \mathrm{H}$.) dalam kitabnya At-Tibyān fì Tafsīr al-Qur'ān, 2. Az-Zamakhsyariy (467-538 H.) dalam kitabnya Al-Kasysyāf, 3. Abū Hayyān al-Andalusiy (654-745 H.) dalam kitabnya Al-Bahr al-Muñith, 4. Ibnu Katsīr (705-774 H.) dalam kitabnya Tafsīr alQur'ān al-'Azhìm, 5. Al-Mahalliy (791-864 H.) dan As-Suyūthiy (849-911 H.) dalam kitab mereka Tafsīr al-Qur'ān al-Karīm (Tafsīr al-Jalālayn), 6. Abū as-Su'ūd (893-982 H.) dalam kitabnya Irsyād al- 'Aql as-Salìm ilā Mazāyā al-Kitāb al-Karīm, 7. Al-Alūsiy (1217-1270 H.) dalam kitabnya Rūh al-Ma'āniy, 8. Al-Qāsimiy (18661914 M.) dalam kitabnya Mahāasin at-Ta'wōl, 9. Aḥmad Mushthafā al-Marāgiy (1883-1952 M.) dalam kitabnya Tafsīr al-Marāgiy, 10. Muhammad 'Aliy ashShābūniy dalam kitabnya Shafwah at-Tafāsīr, 11. Abū Bakr Jābir al-Jazā'iriy dalam kitabnya Aysar at-Tafāsīr, dan 12. Wahbah az-Zuhayliy dalam kitabnya At-Tafsīr alMunīr.
}

250 | Abdullah Karim 
Hadis pertama;

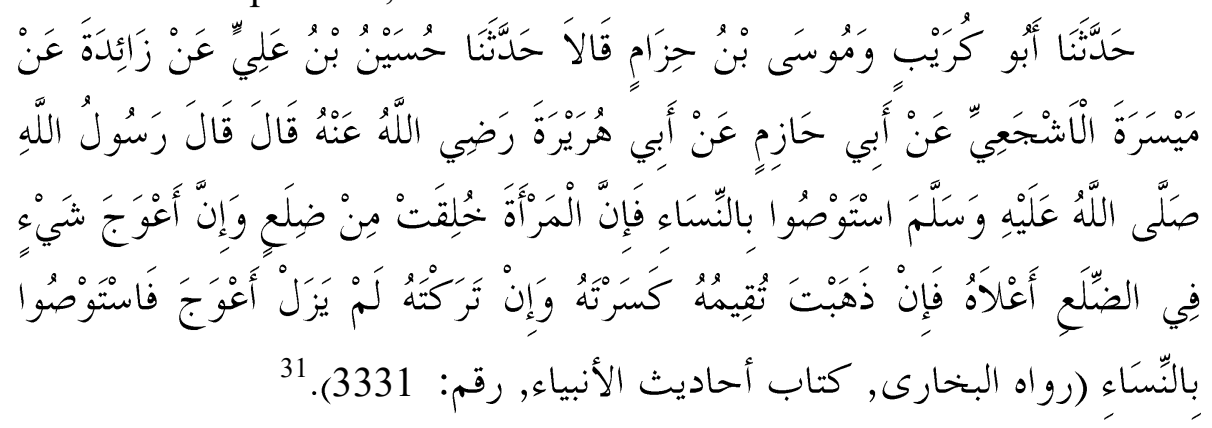

Dari informasi yang terakhir ini, jelas diketahui bahwa AlBukhāriy tidak menempatkan hadis ini dalam bagian tafsirnya, karena hadis dimaksud dia tempatkan pada bagian Ahâadits al-Anbiyā dengan nomor hadis 3331 .

\section{Hadis kedua;}

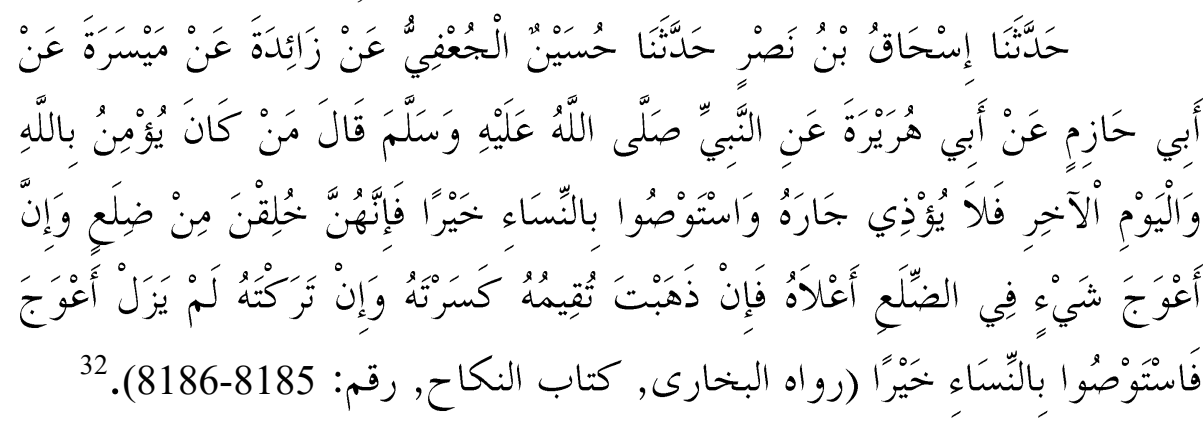

Informasi terakhir ini juga menggambarkan bahwa alBukhāriy tidak menempatkan hadis tersebut dalam bagian tafsirnya, karena hadis ini dia muat dalam Kitāb an-Nikāh dengan nomor hadis 8185 sampai dengan 8186 .

Hadis ini juga diriwayatkan oleh Al-Bukhariy dari gurunya yang lain, yaitu Ishāâq bin Nashr. Akan tetapi untuk sanad berikutnya, yaitu Husayn bin 'Aliy al-Ju'fiy, Zā'idah, Maysarah al-Asyja'iy, Abū Hāaizim dan Abū Hurayrah adalah sama dengan sanad hadis sebelumnya. Matn hadis kedua ini menggunakan ungkapan "hunna" adalah kata ganti yang berarti mereka, yakni semua wanita. ${ }^{33}$ Dengan demikian, penjelasan bahwa Hawwā diciptakan dari tulang rusuk Ādam tidak dapat dipertahankan, karena dari hadis yang kedua ini diketahui bahwa hadis yang semakna ini tidak berbicara secara

${ }^{31}$ Al-Bukhāriy, Shah̄inh al-Bukhāriy, Juz 2, h. 262-263. Terjemahan hadis ini dan seterusnya akan dikemukakan ketika membahas kajian hadis kontekstual.

${ }^{32}$ Al-Bukhāriy, Sha $\underline{h} \underline{h}$ al-Bukhāriy. Juz 3, h. 272-273.

${ }^{33}$ Lihat Al-Bukhāriy, Sha $\underline{h} \underline{\text { h }}$ al-Bukhāriy, Juz 3, h. 273. Hadis nomor 5186. 


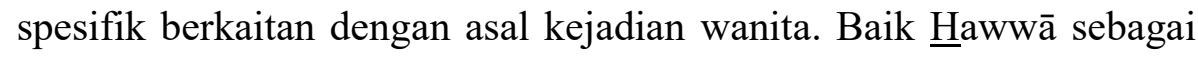
wanita pertama, maupun wanita pada umumnya.

Aksentuasi (penekanan) hadis ini menurut penulis adalah memberikan wasiat yang baik, pesan atau petuah kepada para wanita secara arif dan bijaksana. Hal ini dapat dipahami dari pengulangan ungkapan "fa istawsh $\bar{u}$ bi an-nis $\bar{a}$ " pada hadis pertama, dan " $f a$ istawshü bi an-nisā'i khayran" pada hadis kedua.

Pada hadis yang lain, semakin tampak bahwa hadis semakna tidaklah berbicara secara spesifik tentang kejadian wanita, karena ungkapan " $a d h$-Dhila", digunakan sebagai metafora. Hadis dimaksud adalah sebagai berikut:

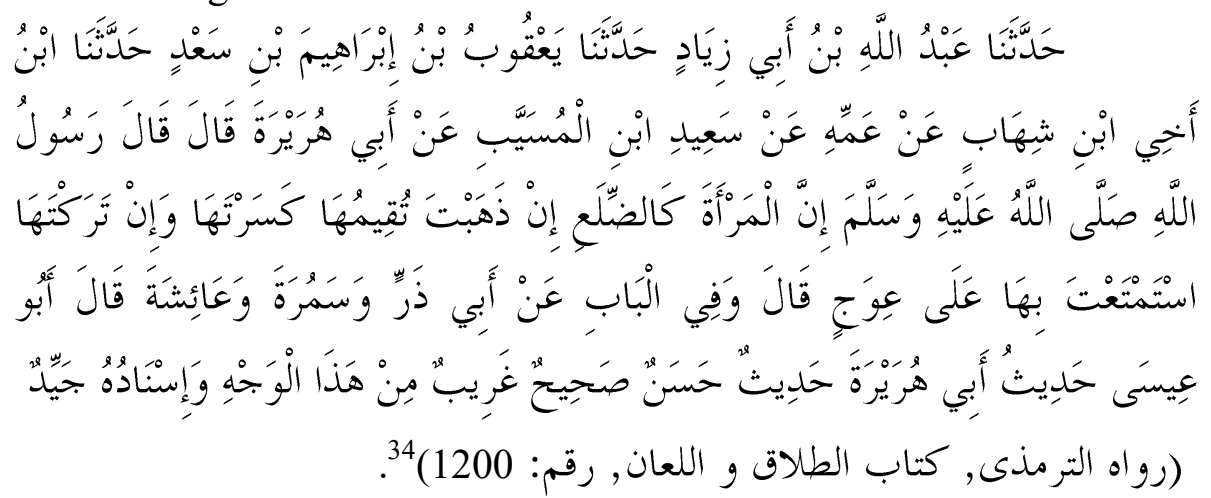

Informasi terakhir ini pun tidak menggambarkan bahwa atTurmudziy memasukkan hadis ini dalam bagian tafsirnya, karena dia memuat hadis ini dalam Kitāb ath-Thalāq wa al-Li'ān dengan nomor hadis 1200 .

Lebih lanjut, apa yang dimaksudkan dengan ungkapan kasartahā yang berarti Anda memecahkannya dalam hadis-hadis yang semakna dengan ketiga hadis di atas adalah menceraikannya atau menalaknya. Untuk itu dapat dilihat hadis berikut:

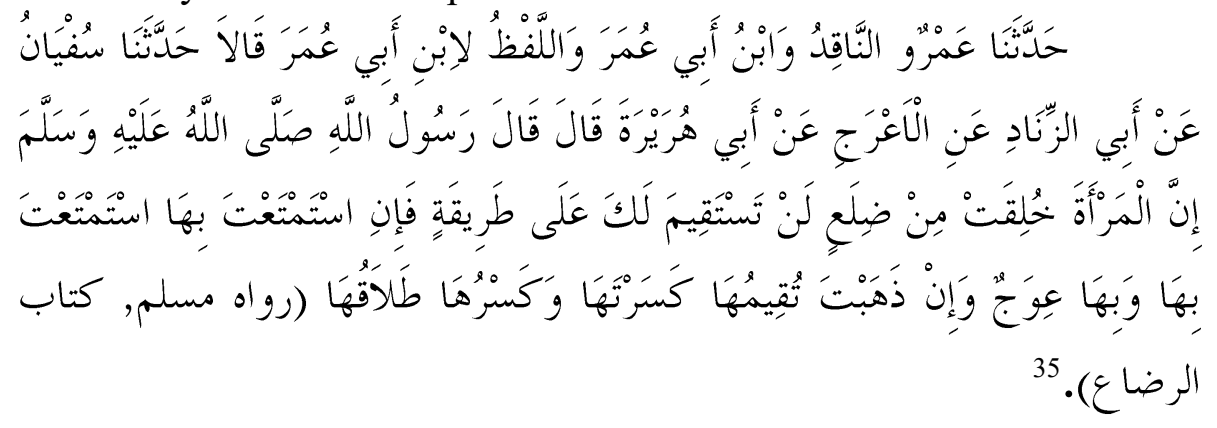

\footnotetext{
${ }^{34} \mathrm{Abū}$ 'Īsā Muhammad bin 'Īsā bin Sūrah at-Turmudziy, Sunan atTurmudziy, Juz 2, (Indonesia: Maktabah Dahlān, t. th.), h. 330.

${ }^{35}$ Muslim, Shahīh Muslim,. Juz 2, h. 1091.
} 
Hadis ini juga, oleh Muslim tidak ditempatkan pada bagian tafsirnya. Dia menempatkannya pada Kitäb ar-Radhä' .

Dari hadis-hadis yang dikutip ini, tampak sekali bahwa para ahli hadis seperti al-Bukhāriy, Muslim dan at-Turmudziy tidak menempatkan hadis-hadis tersebut sebagai penafsir ayat satu Sürah an-Nisā, terutama berkaitan dengan kejadian wanita, lebih khusus lagi kejadian Hawwā, padahal mereka telah mensistematisasi kitab hadis mereka dengan menyediakan Kitāb at-Tafsìr secara khusus. AlBukhāriy memuatnya pada kitāb Anhādìts al-Anbiyā dan kitāb anNikāh , Muslim memuatnya dalam kitāb ar-Radhā', dan at-Turmudziy memuatnya dalam kitāb ath-Thalā wa al-Li'ān.

Dengan menggunakan CD. al-Bayān, program Hadith penulis menelusuri hadis melalui kata "zawjahā" dan penulis temukan 17 hadis semakna, namun tidak ada hadis yang secara langsung dapat dipahami menjelaskan atau menafsirkan Sürah an-Nisā ayat satu. Di samping itu, dari program Hadith juga penulis melacak hadis dengan menggunakan kata Hawwā, tidak penulis temukan hadis yang berkaitan dengan kejadian $\underline{H}$ awwā isteri Ādam. Memang ditemukan kata Hawwā pada Musnad Ahmad bin hanbal, kitāb musnad Küfiyyīn, namun tidak berkaitan dengan kejadian wanita pertama, di situ hanya pemakaian bahasa yang berarti hitam $(\operatorname{sawda}) .{ }^{36}$ Dengan menggunakan CD. Al-Maktabah al- Alfiyyah li as-Sunnah anNabawiyyah penulis juga melacak hadis melalui kata Hawwā, penulis menemukan 18 hadis yang menginformasikan bahwa Hawwā diciptakan dari tulang rusuk Âdam, namun tidak ditempatkan sebagai penafsir ayat satu Sürah an-Nisā.

Muhammad 'Abduh sebagai pembaharu dalam kajian tafsir, menafsirkan ungkapan wa khalaqa minh $\overline{\boldsymbol{a}}$ zawjaha $\overline{\boldsymbol{a}}$ bahwa Allah menciptakan Hawwā dari jenis yang sama dengan Ādam, yaitu samasama manusia. Pendapat ini juga telah dikemukakan oleh ar-Rāziy dan dipilih oleh Abū Muslim. Untuk itu dia mengutip pula Sürah ar-Rūm ayat 21 yang terjemahnya: "Dan di antara tanda-tanda (kekuasaan) Allah, Dia menciptakan bagi kalian isteri-isteri dari jenis kalian sendiri agar kalian menjadi tenang kepadanya dan Dia jadikan rasa cinta dan kasih sayang di antara kalian" dan ayat-ayat lainnya. ${ }^{37}$

Penafsiran yang menggunakan hadis (riwayat) seperti diinformasikan terdahulu, merupakan kreativitas para mufasir, karena Rasul saw. tidak secara tegas menyatakan bahwa hadis itu sebagai penafsir Sürah an-Nisā ayat satu, begitu pula para ahli hadis (baca al-

\footnotetext{
${ }^{36} \mathrm{CD}$. al-Bayān, program Hadith.

${ }^{37}$ Rasyīd Ridhā/Muhammad 'Abduh, Tafsīr al-Qur'ān al- $\underline{\text { Hakim }}$ (alManār), Jilid 4, (Bayrūt, Lubnān: Dār al-Ma’rifah, t. th.), h. 330.
} 
Bukhāriy, Muslim dan at-Turmudziy) tak seorang jua pun dari mereka yang memposisikan hadis tersebut sebagai hadis tafsir. Berbeda halnya dengan penafsiran kata "zhulm" yang bermakna syirk, Nabi secara tegas mengatakan dalam hadisnya berikut:

Hadis 'Abdullāh Ibnu Mas'ūd ra., ia berkata: "Ketika turun

ayat: 'Orang-orang yang beriman dan mereka tidak mencampuradukkan iman mereka dengan kezaliman (zhulm)...'(Q. S. al-An'ām ayat 82). Hal itu dirasakan berat oleh para sahabat Rasulullah saw. dan mereka berkata: 'Siapa di antara kami yang tidak menzalimi dirinya?' Rasulullah saw. lalu bersabda, hal itu tidak seperti yang kalian duga, pengertiannya adalah seperti nasihat Luqman kepada anaknya: 'Sesungguhnya kesyirikan itu adalah kezaliman yang sangat besar' (Q. S. Luqmān ayat 13).

Dengan demikian, berdasarkan analisis hadis secara proporsional dan profesional penggunaan hadis dimaksud sebagai penafsir Alquran dianggap tidak akurat, jika diklasifikasikan sebagai at-Tafsīr al-Ma'tsūr (penafsiran tekstual).

\section{Kajian Hadis Kontekstual}

Kajian hadis kontekstual ini dimaksudkan agar dapat memperoleh pemahaman yang komprehensif tentang makna hadis. Kadang-kadang ada satu hadis, yang jika dipahami secara harfiah membawa kepada pemahaman tertentu. Akan tetapi, jika hadis-hadis yang berkaitan dengan satu tema dihimpun dan dipahami secara tematis, maka akan ditemukan pemahaman lain yang komprehensif. Hal ini pernah penulis temukan ketika meneliti penafsiran Sürah anNis $\bar{a}$ ayat satu, yang mana para mufasir yang menggunakan riwayat sebagai penafsirnya, berkesimpulan bahwa Hawwā diciptakan dari tulang rusuk Âdam.

Untuk lebih jelasnya mengenai hadis tersebut, akan penulis kutip terjemahan hadis-hadis dimaksud selengkapnya sebagai berikut:

Abū Kurayb dan Mūsā bin Hizām menyampaikan hadis ini kepada kami. Keduanya mengatakan: "Husayn bin 'Aliy menyampaikan hadis ini kepada kami”. Dari Zā'idah, dari Maysarah al-Asyja'iy, dari Abū Hāzim dari Abū Hurayrah ra. Ia berkata: Bersabda Rasulullah saw.: "Berwasiatlah kalian kepada para wanita, karena seorang wanita itu diciptakan dari tulang rusuk dan tulang rusuk yang paling bengkok adalah tulang rusuk yang paling tinggi (panjang). Jika Anda meluruskannya, (berarti) Anda memecahkannya, namun jika Anda biarkan saja, ia akan selalu bengkok. Oleh karena itu, maka berwasiatlah kepada para wanita”. (H. R. al-Bukhāriy, kitāb (dalam arti bagian) A $\underline{h} \bar{a} d \bar{t} t s$ al-Anbiȳā, nomor 3331). 
Dalam teks hadis ini barangkali dapat dipahami bahwa yang

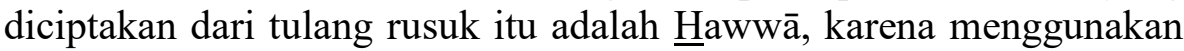
ungkapan "al-mar'ah" yang berarti seorang perempuan dan "khuliqat" yang berarti dia diciptakan, kata ganti di sini kembali kepada kata al-mar'ah. Akan tetapi jika diperhatikan hadis lain yang dikemukakan oleh al-Bukhāriy juga, maka yang diciptakan dari tulang rusuk itu, bukan hanya Hawwā, isteri Ādam, tetapi semua wanita, sebagaimana hadis berikut ini:

Ishāa bin Nashr menyampaikan hadis ini kepada kami. Ia mengatakan: "Husayn al-Ju'fiy menyampaikan hadis ini kepada kami”. Dari Zā’idah, dari Maysarah, dari Abū Hāzim, dari Abū Hurayrah, dari Nabi saw., beliau bersabda: "Siapa pun yang beriman kepada Allah dan Hari Akhir, maka janganlah orang itu menyakiti tetangganya. Dan hendaklah kalian berwasiat yang baik kepada para wanita, karena sesungguhnya mereka diciptakan dari tulang rusuk dan tulang yang paling bengkok adalah yang paling tinggi (panjang). Jika Anda berusaha meluruskannya (berarti) Anda memecahkannya, namun jika Anda membiarkannya, ia akan selalu bengkok. Oleh karena itu hendaklah kalian berwasiat yang baik kepada para wanita".

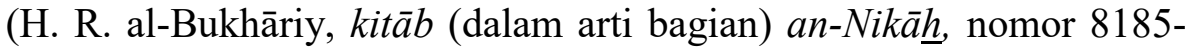
8186).

Abdullah bin Abū Ziyād menyampaikan hadis ini kepada kami. Ia mengatakan: "Ya'qūb bin Ibrāhīm bin Sa'd menyampaikan hadis ini kepada kami”. Ia mengatakan: "Keponakan Ibnu Syihāb menyampaikan hadis ini kepada kami”. Dari pamannya (Ibnu Syihāb), dari Sa'īd bin al-Musayyab, dari Abū Hurayrah. Ia mengatakan: Rasulullah saw. bersabda: "Sesungguhnya wanita itu bagaikan tulang rusuk, jika Anda meluruskannya (berarti) Anda memecahkannya, namun jika Anda membiarkannya, Anda bersenang-senang dengannya atas kebengkokan". At-Turmudziy mengatakan dalam bab ini ada pula riwayat yang berasal dari Abū Dzarr, Samurah, dan ' $\bar{A}$ 'isyah. Selanjutnya ia mengatakan pula: Hadis Abū Hurayrah ini Hasan Shahㅡㄴ garīb dari sanad ini (artinya semula berkualitas $\underline{H}$ asan, namun didukung oleh hadis lainnya yang berkualitas Shahㅡㄴ dan para periwayatnya untuk masing-masing angkatan (baca thabaqah) hanya satu orang). Walaupun demikian, menurut at-Turmudziy sanad hadis ini baik (jayyid) (H. R. at-Turmudziy, kitāb (dalam arti bagian) athThalāq wa al-Li'ān, nomor 1200).

Dalam hadis ini Nabi saw. menggunakan ungkapan " $k a$ adhDhila'i” yang berarti bagaikan tulang rusuk, sebagai bentuk metafora. Dari hadis yang ketiga ini, semakin tampak bahwa sasaran hadis bukanlah untuk menjelaskan asal kejadian wanita. Masih ada hadis-hadis lain semakna yang menggunakannya sebagai metafora, 
sehingga dapat dipahami dalam arti konotasi (majazi) bukan dalam arti denotasi (hakiki).

'Amrun an-Nāqid dan Ibnu Abī 'Umar menyampaikan hadis ini kepada kami. Lafal hadis ini berasal dari Ibnu Abī 'Umar. Mereka berdua berkata: "Sufyān menyampaikan hadis ini kepada kami". Dari Abū az-Zinād, dari al-A'raj, dari Abū Hurayrah. Ia mengatakan: "Rasulullah saw. bersabda: 'Sesungguhnya wanita itu diciptakan dari tulang rusuk. Selamanya ia tidak akan dapat lurus untukmu atas satu cara. Maka jika Anda bersenang-senang dengannya, (berarti) Anda bersenang-senang dengannya sedangkan ia dalam keadaan bengkok, namun jika Anda meluruskannya, (berarti) Anda memecahkannya. Pecahnya itu adalah menalaknya. (H. R. Muslim, kitāb ar-Radhā').

Dari uraian terdahulu, jika hadis-hadis semakna dicermati secara proporsional dan profesional, maka dapat dikatakan bahwa hadis-hadis yang dijadikan sandaran oleh para mufasir dalam menafsirkan kejadian Hawwā dari tulang rusuk Ādam, bukanlah esensi konteks hadis, karena secara kontekstual hadis-hadis tersebut menekankan perlunya memberikan wasiat, pesan, bimbingan, petunjuk dan arahan kepada para wanita (baca isteri) dengan cara arif dan bijaksana, karena wanita itu bagaikan tulang rusuk yang bengkok, sangat sulit (kalau tidak enggan mengatakan mustahil) untuk meluruskannya. Sekiranya tulang rusuk tersebut dapat diluruskan, maka lurusnya itu berarti pecah. Pecahnya tulang rusuk tersebut sebagai gambaran (konotasi bukan denotasi) terjadinya talak terhadap isteri. Demikian informasi langsung dari redaksi hadis yang berkaitan dengan hal tersebut.

\section{Kesimpulan}

Setelah mengemukakan uraian terdahulu, pada bagian akhir ini akan ditarik kesimpulan sebagai berikut:

1. Penafsiran Alquran secara tekstual merupakan penafsiran terbaik, selama riwayat-riwayat yang digunakan sebagai penafsir itu dapat dipertanggungjawabkan keabsahannya.

2. Keabsahan hadis yang dijadikan penafsir Alquran dimaksud harus memenuhi kriteria berikut: a. Penafsiran Alquran dengan Alquran harus bersumber dari Rasul saw. sendiri. b. Penafsiran Alquran dengan hadis harus berdasarkan periwayatan yang shahīh $\underline{\text {. c. }}$ Berkaitan dengan riwayat $a s b \bar{a} b$ an-nuz $\bar{u} l$ harus menggunakan riwayat yang ungkapannya secara tegas menunjukkan sebab turun ayat. d. Keabsahan riwayat yang dijadikan penafsir Alquran tersebut akan lebih akurat jika mempertimbangkan proporsionalitas, profesionalitas dan kontekstualitas hadis-hadis dimaksud. 


\section{DAFTAR PUSTAKA}

Al-'Akk, Asy-Syaykh Khālid 'Abd ar-Rahmān, Ushūl at-Tafsīr wa Qawā'iduh, Cet. ke-2; Bayrūt: Dār an-Nafā'is, 1406 H./1986 M.

Amīn, Bakriy Syaykh, at-Ta 'bīr al-Fanniy fì al-Qur'ān al-Karīm, Cet. ke-1; Bayrūt, Lubnān: Dār al-'Ilmi li al-Malāyīn, 1994.

Al-Bukhāriy, Abū 'Abdillāh Muhammad bin Ismā'îl bin Ibrāhīm bin al-Mugīrah bin Bardizbah, Sha $\underline{h} \underline{h}$ al-Bukhāriy bi $\underline{H} \bar{a} s y i y a h$ asSindiy, Juz 1, 2 dan 3, Bayrūt, Lubnān: Dār al-Fikr, 1414 H./1994 M.

Ad-Dimasyqiy, Ibrāhīm bin Muhammad bin Kamāl ad-Dīn asy-Syahīr

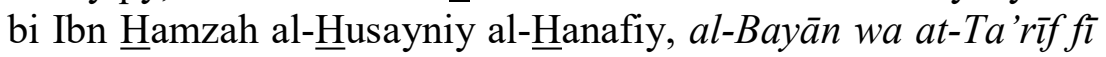

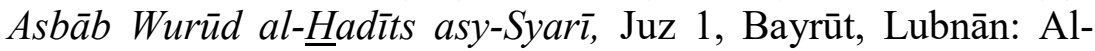
Maktabah al-'Ilmiyyah, 1402 H./1982 M.

Adz-Dzahabiy, Muhammad Husayn, at-Tafsīr wa al-Mufassirūn Juz 1, Cet. ke-8, al-Qāhirah: Maktabah Wahbah, 1424 H./2003 M.

Al-Farmāwiy, 'Abd al-Hayy, al-Bidāyah fì at-Tafsìr al-Mawdhū'iy, Cet. ke-7, al-Qāhirah: Fakultas Ushuluddin Universitas al-Azhar, 1425 H./2005 M.

Ibnu 'Āsyūr, Muhammad al-Fādhil, At-Tafsīr wa Rijāluh, al-Qāhirah: Majma’ al-Buhūts al-Islāmiyyah, 1390 H./1970 M.

Ibnu Taymiyah, Muqaddimah fì Ushūl at-Tafsīr, Cet. ke-2; Bayrūt, Lubnān: Dār Ibni Hazm, 1418 H./1997 M.

Al-Khālidiy, Shalāh 'Abd al-Fattāḥ, Ta'rīf ad-Dārisīn bi Manāhij alMufassirīn, Cet. ke-1; Damsyiq: Dār al-Qalam/Bayrūt: ad-Dār asy-Syāmiyah, 1423 H./2002 M.

Karim, Abdullah, Reinterpretasi Ayat-Ayat Bias Gender (Interpretasi Analitis Sūrah an-Nisā Ayat Satu dan 34), Banjarmasin: Puslit IAIN Antasari, 2003.

Al-Masyīniy, Mushthafā Ibrāhīm, Madrasah al-Tafsīr fì al-Andalus, Cet. ke-1, Bayrūt: Mu'assasah ar-Risālah, 1406 H./1986 M. 
Muhammad, 'Abd ar-Rahīm Muhammad, At-Tafsīr an-Nabawiy: Khashā'ishuh wa Mashādiruh, Cet. ke-1; al-Qāhirah: Maktabah az-Zahrā, 1413 H./1992 M.

An-Nasā'iy, Abū 'Abd ar-Rahmān Ahmad bin Syu'ayb, Sunan anNasā'iy bi Syarh as-Suyūthiy wa Hāasyiyah as-Sindiy, Juz 8, Semarang: Toha Putra, t. th.

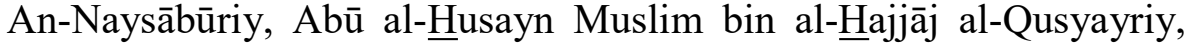
Shah̄inh Muslim bi Syarh an-Nawawiy, Juz 2, Indonesia: Maktabah Dahlān, t. th.

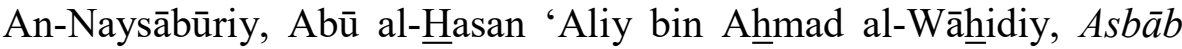
an-Nuzūl, Jakarta: Dinamika Berkah Utama, t.th.

Qaththān, Mannā', Mabāhits fì 'Ulūm al-Qur'ān, Riyādh: Mansyūrāt

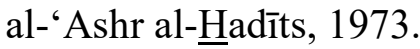

Ar-Rūmiy, Fahd 'Abd ar-Rahmān bin Sulaymān, Ushūl at-Tafsīr wa Manāhijuh, Cet. ke-1; Riyādh: Maktabah at-Tawbah, 1413.

Ash-Shābūniy, Muhammad 'Aliy, at-Tibyān fì 'Ulūm al-Qur'ān, Cet. ke-1; Jakarta: Dār al-Kutub al-Islāmiyyah, 1424 H./2003 M.

As-Suyūthiy, Jalāl ad-Dīn Abū al-Fadhl 'Abd ar-Rahnmān, Tadrīb arRāwiy Syarh Taqrīb an-Nawawiy, tahqīq 'Irfān al-'Asyā Hasūnah, Bayrūt, Lubnān: Dār al-Fikr,1420 H./2000 M.

At-Turmudziy, Abū 'sā Muhammad bin 'sā bin Sūrah, Sunan atTurmudziy, Juz 2, Indonesia: Maktabah Dahlān, t. th.

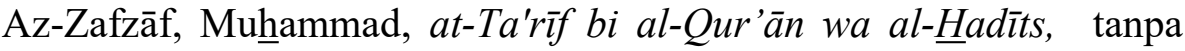
data.

Zaglūl, Muhammad Hamd, at-Tafsīr bi al-Ra'yi: Qawā'iduh wa Dhawābithuh wa A'lāmuh, Cet. ke-1; Damsyiq: Maktabah alFārābiy, 1420 H./1999 M.

Az-Zarkasyy, Badr ad-Dīn Muhammad bin 'Abdullāh, Al-Burhān fì 'Ulūm al-Qur'ān, Juz 2, Bayrūt, Lubnān: Dār al-Fikr, 1408 H./1988 M. 
Az-Zarqāniy, Muhammad 'Abd al-'Azhīm, Manāhil al-'Irfān fì 'Ulūm al-Qur'ān, Jilid 2, Bayrūt: Dār al-Fikr, t. th. 
260 Abdullah Karim 